\title{
Submicromolar $\mathrm{La}^{3+}$ concentrations block the calcium release-activated channel, and impair CD69 and CD25 expression in CD3- or thapsigargin- activated Jurkat cells
}

\author{
Claude AUSSEL ${ }^{*}$, Rachid MARHABA, Claudette PELASSY and Jean-Philippe BREITTMAYER \\ INSERM U343, Hôpital de I'Archet, BP 79, 06202 Nice cédex 03, France
}

\begin{abstract}
The calcium release-activated channel (CRAC) opened in Jurkat cells activated either with CD3 monoclonal antibody or the endoplasmic reticulum $\mathrm{Ca}^{2+}$-ATPase blocker, thapsigargin, is blocked by $\mathrm{La}^{3+}$ with an $\mathrm{IC}_{50}$ of $20 \mathrm{nM}$. Similarly, the entry of $\mathrm{Mn}^{2+}$, used as a surrogate for $\mathrm{Ca}^{2+}$, is also blocked by submicromolar $\mathrm{La}^{3+}$ concentrations. $\mathrm{La}^{3+}$ seems to play its role simply by plugging the CRAC because this ion does not penetrate the cells,
\end{abstract}

as demonstrated by chelation experiments with EGTA. Blocking the $\mathrm{Ca}^{2+}$ influx in activated Jurkat cells results in a lack of expression of CD25, a chain of the interleukin-2 receptor and of CD69, a marker of T-cell activation. By contrast, the very early steps of the T-cell signalling pathway such as the release of $\mathrm{Ca}^{2+}$ from intracellular stores and the subsequent inhibition of phosphatidylserine synthesis are not affected by $\mathrm{La}^{3+}$.

\section{INTRODUCTION}

In Jurkat $\mathrm{T}$ cells, activation of the T-cell receptor (TCR)-CD3 complex results in recruitment of tyrosine kinases that are members of the $\operatorname{src}$ family including $f y n$ and $l c k$. It has been proposed that the src family of tyrosine kinases activate a phospholipase $\mathrm{C}$ isoform, $\gamma 1$, which in turn stimulates phosphoinositide hydrolysis, leading to the generation of inositol 1,4,5trisphosphate $\left(\mathrm{IP}_{3}\right)$ [1-3]. $\mathrm{IP}_{3}$ triggers intracellular calcium release $[4,5]$. Emptying of the intracellular calcium stores generates a $\mathrm{Ca}^{2+}$ influx through a calcium release-activated channel (CRAC), possibly opened by a calcium influx factor (CIF) as described by Randriamampita and Tsien [6]. The first steps involved in T-cell activation are bypassed when using the endoplasmic reticulum $\mathrm{Ca}^{2+}$-ATPase blocker, thapsigargin [7,8]. This compound passively decreases the $\mathrm{Ca}^{2+}$ level in the endoplasmic reticulum, allowing the CRAC to open. The effects of $\mathrm{La}^{3+}$ on $\mathrm{Ca}^{2+}$ signalling have been previously tested in lachrymal cells (in the range $30-500 \mu \mathrm{M}$ ) [9], in salivary acinar cells at $1 \mathrm{mM}$ [10] and in C6-2B glioma cells at $200 \mu \mathrm{M}$ [11]. At these high concentrations, $\mathrm{La}^{3+}$ has been shown to inhibit membrane $\mathrm{Ca}^{2+}$-ATPase and $\mathrm{Ca}^{2+}$ entry in cells treated with thapsigargin. We show here that in Jurkat $\mathrm{T}$ lymphocytes, submicromolar $\mathrm{La}^{3+}$ concentrations block capacitative $\mathrm{Ca}^{2+}$ entry as well as $\mathrm{Mn}^{2+}$ entry (when $\mathrm{Mn}^{2+}$ was used as a surrogate for $\mathrm{Ca}^{2+}$ ). Activation of $\mathrm{T}$ cells via the TCR can be monitored by measuring the expression of CD25 and CD69. CD25 is a $55 \mathrm{kDa}$ protein that forms a low-affinity receptor for interleukin-2 (IL-2). CD25, when associated with the $75 \mathrm{kDa}$ component of the IL-2 receptor, forms a heterodimer of high affinity for this interleukin. CD69, a disulphide-linked dimeric structure including a $33 \mathrm{kDa}$ and a $27 \mathrm{kDa}$ chain, is the earliest molecule that appears de novo on the lymphocyte surface on activation. We show here that blocking $\mathrm{Ca}^{2+}$ entry induced by TRC activation results in a lack of surface expression of both CD25 and CD69.

\section{MATERIALS AND METHODS \\ Cells}

The human T-cell line Jurkat was kindly supplied by Dr. A. M. Schmitt-Verhulst (Centre d'Immunologie, Marseille-Luminy, France). Cells were cloned by limiting dilution. Clone D was selected on the basis of its IL-2 production when activated with phytohaemagglutinin and phorbol 12-myristate 13-acetate. Cells were cultured in RPMI 1640 medium (Seromed, Lille, France) supplemented with $5 \%$ (w/v) fetal calf serum, 50 i.u. $/ \mathrm{ml}$ penicillin, $50 \mu \mathrm{g} / \mathrm{ml}$ streptomycin, $2 \mathrm{mM} \mathrm{L-glutamine}$ and $1 \mathrm{mM}$ pyruvate.

\section{Measurements of changes in cytosolic $\left[\mathrm{Ca}^{2+}\right]$}

The assay of cytosolic $\left[\mathrm{Ca}^{2+}\right]$ was performed by using Indo-1 (Calbiochem) [12]. Cells $\left(5 \times 10^{6} / \mathrm{ml}\right)$ were loaded by using $5 \mu \mathrm{M}$ Indo- 1 at $37^{\circ} \mathrm{C}$ in the dark for $1 \mathrm{~h}$ and then washed and resuspended in Hepes buffered saline $(140 \mathrm{mM} \mathrm{NaCl}, 5 \mathrm{mM}$ $\mathrm{KCl}, 1 \mathrm{mM} \mathrm{CaCl}{ }_{2}, 1 \mathrm{mM} \mathrm{MgCl}, 10 \mathrm{mM}$ glucose, $20 \mathrm{mM}$ Hepes, $0.1 \%$ BSA, pH 7.4). When necessary, calcium was omitted. The analyses were performed on a fluorescence-activated cell sorter (FACStar Plus, Becton Dickinson) fitted with two argon lasers, one tuned to $488 \mathrm{~nm}(250 \mathrm{mV})$ to gate out debris and damaged cells according to the dual-scatter dot plot, and the other to UV (100 mV, 351-364 nm) to excite Indo-1 fluorescence. The fluorescence intensities at 480 and $400 \mathrm{~nm}$, corresponding to the free Indo-1 and the complex $\mathrm{Ca}^{2+}-$ Indo-1 concentrations respectively, were measured. Calculation of the ratio of fluorescence at $400 \mathrm{~nm}$ to that at $480 \mathrm{~nm}$ allows the evaluation of changes in cytosolic free $\mathrm{Ca}^{2+}$ concentration $\left(\left[\mathrm{Ca}^{2+}\right]_{\mathrm{i}}\right)$ independently of the cell size and the intracellular Indo- 1 concentration. The flow rate was set to 1000 cells/s and the mean ratio of 3000 cells was noted every $30 \mathrm{~s}$. 


\section{Measurement of $\mathrm{Mn}^{2+}$ entry}

$\mathrm{Mn}^{2+}$ uptake was monitored by the quenching of the Indo-1 fluorescence at $430 \mathrm{~nm}$, which is insensitive to variations in $\left[\mathrm{Ca}^{2+}\right]_{\mathrm{i}}$.

\section{Phosphatidylserine synthesis}

Jurkat cells $\left(2 \times 10^{6}\right)$ were maintained in $0.5 \mathrm{ml}$ of a buffer (pH 7.4) containing $137 \mathrm{mM} \mathrm{NaCl}, 2.7 \mathrm{mM} \mathrm{KCl}, 2.5 \mathrm{mM}$ glucose, $20 \mathrm{mM}$ Hepes, $1 \mathrm{mM} \mathrm{MgCl}$ and $1 \mathrm{mM} \mathrm{CaCl}_{2}$ at $37^{\circ} \mathrm{C}$ in the presence of $4 \mu \mathrm{Ci} / \mathrm{ml}\left[{ }^{3} \mathrm{H}\right]$ serine $(0.37-1.1 \mathrm{TBq} / \mathrm{mmol}$, Amersham, Les Ulis, France) and effectors as indicated in the legends to the Figures. After incubation for $0-2 \mathrm{~h}$ the cells were rapidly sedimented in an Eppendorf centrifuge, the supernatants discarded and the cell phospholipids extracted with chloroform/ methanol by the method of Bligh and Dyer [13]. The lipid extracts were analysed by TLC in a solvent system composed of chloroform/methanol/acetic acid/water (75:45:12:3). Authentic phospholipid standards (Sigma) were run in parallel and detected with iodide vapours. Radioactivity in lipid spots was determined by using an automatic linear radiochromatography analyser (Berthold).

\section{Measurements of CD69 and CD25}

Cells $\left(10^{6} / \mathrm{ml}\right)$ were incubated for $24 \mathrm{~h}$ in RPMI $1640 / 5 \%$ fetal calf serum, in the presence of phorbol 12-myristate 13-acetate $\left(10^{-8} \mathrm{M}\right)$ and CD3 $(2 \mu \mathrm{g} / \mathrm{ml})$ or thapsigargin $\left(10^{-7} \mathrm{M}\right)$, with or without the $\mathrm{Ca}^{2+}$ entry blockers SK\&F $96365(3 \mu \mathrm{M})$ or $\mathrm{La}^{3+}$ $(1 \mu \mathrm{M})$, then washed and tested for the expression of CD25 and CD69 antigen. CD25 monoclonal antibody (mAb) conjugated to phycoerythrin and CD69 mAb conjugated to fluorescein isothiocyanate (Becton Dickinson) were used to detect the expression of their respective antigens by cytofluorimetry.

\section{RESULTS}

\section{$\mathrm{La}^{3+}$ blocks CD3-induced Ca ${ }^{2+}$ entry}

When assayed in a medium containing $1 \mathrm{mM} \mathrm{Ca}^{2+}, \mathrm{CD} 3 \mathrm{mAb}$ induces a strong increase in $\left[\mathrm{Ca}^{2+}\right]_{i}$. This rise is the result of two effects: a release of $\mathrm{Ca}^{2+}$ from the intracellular compartment and a $\mathrm{Ca}^{2+}$ influx. The effect of different concentrations of $\mathrm{La}^{3+}$ on CD3-induced $\mathrm{Ca}^{2+}$ signals is shown in Figure 1A. It appears that $\mathrm{La}^{3+}$ inhibits the sustained elevation of $\left[\mathrm{Ca}^{2+}\right]_{\mathrm{i}}$ but allows a transient increase, presumably due to the release of $\mathrm{Ca}^{2+}$ from intracellular stores. The inhibition of the $\left[\mathrm{Ca}^{2+}\right]_{\mathrm{i}}$ plateau occurred with an $\mathrm{IC}_{50}$ of $40 \mathrm{nM}$ (Figure 1B). When stimulations occurred in a low- $\left[\mathrm{Ca}^{2+}\right]$ medium (about $10^{-5} \mathrm{M}$, owing to contaminations) the initial rise of $\left[\mathrm{Ca}^{2+}\right]_{\mathrm{i}}$ was not affected by $\mathrm{La}^{3+}$ (Figure $1 \mathrm{C}$ ); on the contrary, the second $\left[\mathrm{Ca}^{2+}\right]_{i}$ increase after the addition of $1 \mathrm{mM} \mathrm{Ca}^{2+}$ in the medium was greatly dependent on the presence
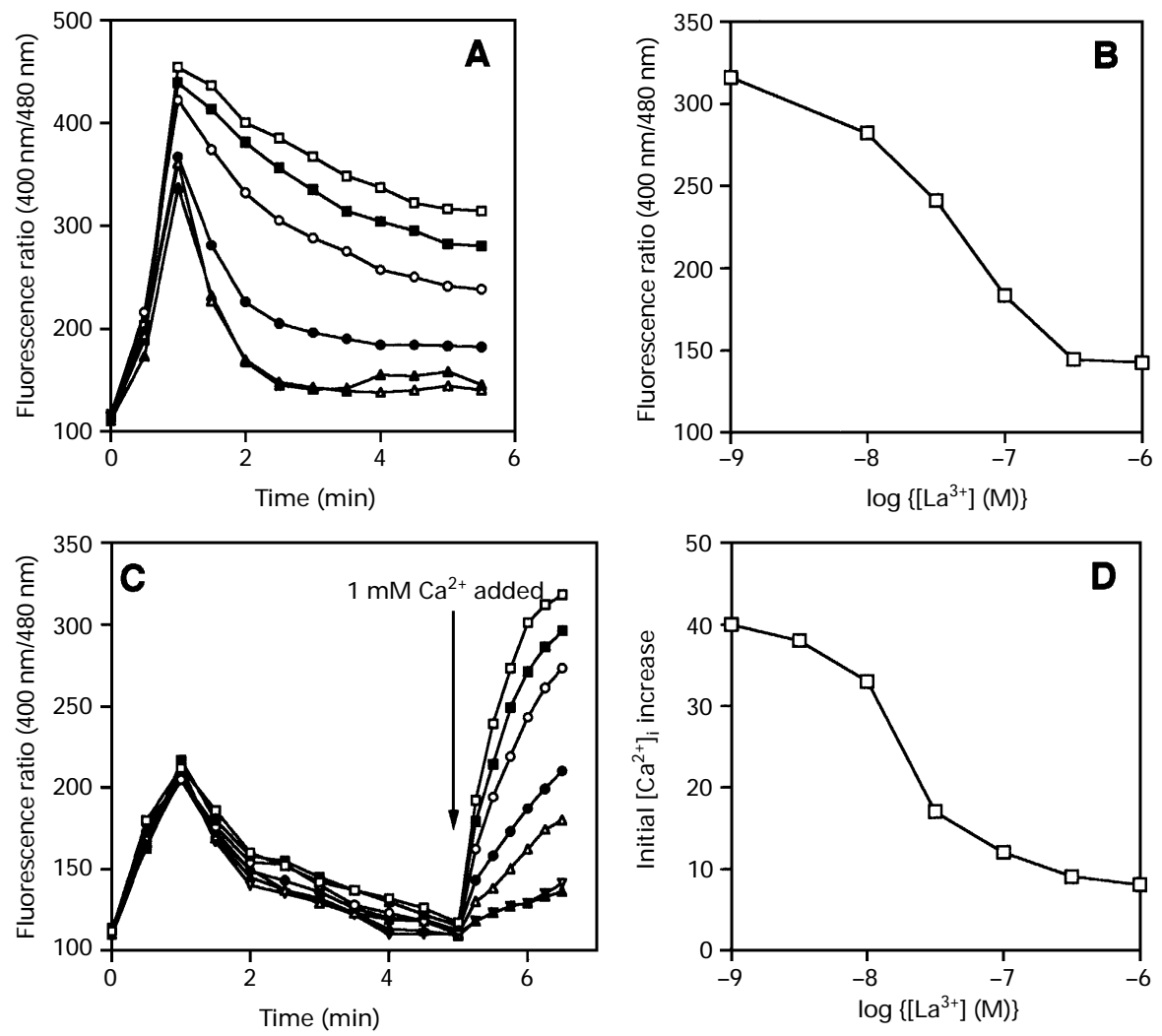

Figure 1 Inhibition of $\mathrm{Ca}^{2+}$ influx in CD3-activated Jurkat cells

(A) Cells maintained in medium containing $1 \mathrm{mM} \mathrm{Ca}^{2+}$ were treated at time 0 with different concentrations of $\mathrm{La}^{3+}$ and $5 \mu \mathrm{g} / \mathrm{ml} \mathrm{CD3}$ monoclonal antibody. [ $\left.\mathrm{Ca}^{2+}\right]_{\mathrm{i}}$ was followed by measuring the change in the 400/480 $\mathrm{nm}$ fluorescence ratio of Indo-1. (B) The level of the $\mathrm{Ca}^{2+}$ plateau at time 5 min plotted against the $\mathrm{La}^{3+}$ concentration. (C) Cells maintained in a nominally $\mathrm{Ca}^{2+}$-free medium were treated at time 0 with different concentrations of $\mathrm{La}^{3+}$ and $5 \mu \mathrm{g} / \mathrm{ml} \mathrm{CD3}$ monoclonal antibody. At time $4 \mathrm{~min} 30 \mathrm{~s}, 1 \mathrm{mM} \mathrm{CaCl}_{2}$ was added to the cell suspension and $\left[\mathrm{Ca}^{2+}\right]_{i}$ was followed for an additional $2 \mathrm{~min}$. (D) The slope of the second $\left[\mathrm{Ca}^{2+}\right]_{\mathrm{i}}$ rise plotted against $\mathrm{La}^{3+}$ concentration. 


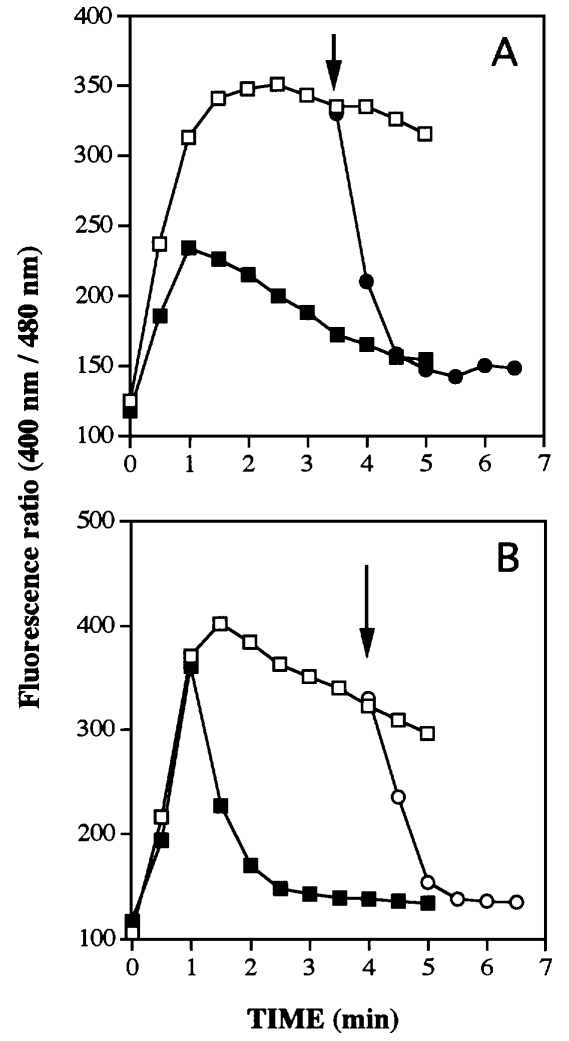

Figure 2 Changes in $\left[\mathrm{Ca}^{2+}\right]_{i}$ induced in Jurkat cells by thapsigargin $(A)$ or CD3 monoclonal antibody (B)

The fluorescence of Indo-1 was measured in cells treated either with thapsigargin or CD3 alone $(\square)$, in cells treated with $500 \mathrm{nM} \mathrm{La}^{3+}$ added to the cell suspension at time 0 just before CD3 or thapsigargin $(\mathbf{\square})$ and in cells treated with either $\mathrm{CD} 3$ or thapsigargin at time 0 and then with $500 \mathrm{nM} \mathrm{La}{ }^{3+}$ at time 4 min (indicated by an arrow) $(-O)$. The $\mathrm{Ca}^{2+}$ concentration in the medium was $1 \mathrm{mM}$. The Figure is representative of three independent experiments.

of $\mathrm{La}^{3+}$, with an $\mathrm{IC}_{50}$ of $20 \mathrm{nM}$ (Figure 1D). $\left[\mathrm{Ca}^{2+}\right]_{\mathrm{i}}$ elevation was inhibited by $\mathrm{La}^{3+}$ when the cells were preincubated for $5 \mathrm{~min}$ before the CD3 treatment and also when $\mathrm{La}^{3+}$ was applied $3 \mathrm{~min}$ after CD3 mAb (Figure 2B). Similar results were obtained with cells treated with the endoplasmic reticulum $\mathrm{Ca}^{2+}$-ATPase blocker, thapsigargin (Figure 2A). In previous papers we have shown that emptying intracellular stores of Jurkat cells inhibited the base-exchange enzyme system responsible for phosphatidylserine (PtdSer) synthesis [14,15]. Measuring PtdSer synthesis was thus used as a tool to verify the status of intracellular $\mathrm{Ca}^{2+}$ stores $[16,17]$. PtdSer synthesis was inhibited both by CD3 mAb and thapsigargin and this process was not influenced by $\mathrm{La}^{3+}$ even at high concentrations (results not shown).

\section{La $^{3+}$ does not act by penetrating Jurkat cells}

It is accepted that $\mathrm{La}^{3+}$ does not penetrate cells even at very high concentrations. To verify this point, cells were first treated with $1 \mu \mathrm{M} \mathrm{La}^{3+}$, followed immediately by CD3 mAb. Under these conditions, only a peak of $\mathrm{Ca}^{2+}$ due to the release of $\mathrm{Ca}^{2+}$ from intracellular stores was seen (Figure 3). Then, at $4 \mathrm{~min}, 10 \mu \mathrm{M}$ EGTA was added to the cell suspension. At this concentration, EGTA was unable to chelate a significant amount of $\mathrm{Ca}^{2+}$ that was present at $1 \mathrm{mM}$ but was quite able to chelate $1 \mu \mathrm{M} \mathrm{La}^{3+}$ owing to its very high affinity for that ion. Under these experimental conditions, the effect of $\mathrm{La}^{3+}$ was fully reversed by EGTA

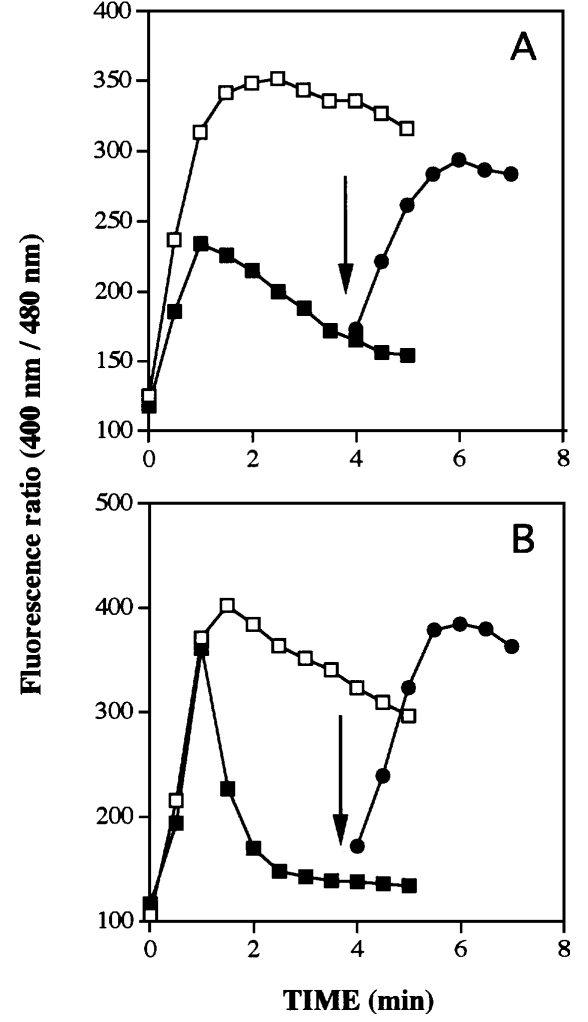

Figure 3 EGTA $(10 \mu \mathrm{M})$ reverses the effect of $\mathrm{La}^{3+}$

Jurkat cells were treated at time 0 with $10^{-7} \mathrm{M}$ thapsigargin $(\mathbf{A})$ or $\mathrm{CD} 3 \mathrm{mAb}(\mathbf{B})$ alone $(\square)$ or in the presence of $500 \mathrm{nM} \mathrm{La}{ }^{3+}(\mathbf{\square})$. At time 4 min (indicated by an arrow), $10 \mu \mathrm{M} \mathrm{EGTA}$ was added $(\mathbf{O})$ to chelate $\mathrm{La}^{3+}$, and $\left[\mathrm{Ca}^{2+}\right]_{\mathrm{i}}$ was followed for an additional $3 \mathrm{~min}$. The $\mathrm{Ca}^{2+}$ concentration in the medium was $1 \mathrm{mM}$. Similar results where obtained from two independent experiments.

and the $\mathrm{Ca}^{2+}$ entry recovered its previous ability. Identical results were observed with cells activated either with $\mathrm{CD} 3 \mathrm{mAb}$ or thapsigargin (Figures 3A and 3B).

\section{$\mathrm{La}^{3+}$ blocks $\mathrm{Mn}^{2+}$ entry}

$\mathrm{Mn}^{2+}$ can be used as a $\mathrm{Ca}^{2+}$ surrogate to estimate $\mathrm{Ca}^{2+}$ influx through the plasma membrane [18-20]. Figure 4 shows that $\mathrm{Mn}^{2+}$ entry into Jurkat cells as measured by the quenching of Indo-1 fluorescence at $430 \mathrm{~nm}$ is inhibited by $\mathrm{La}^{3+}$. Similar results were obtained whether the cells were activated with CD3 $\mathrm{mAb}$ or thapsigargin.

\section{$\mathrm{La}^{3+}$ inhibits CD69 and CD25 expression}

It is well known that the membrane expression of CD69 and CD25 reflects the state of activation of T lymphocytes. To see whether blocking the $\mathrm{Ca}^{2+}$ channel modifies T-cell activation, we measured the expression of both CD69 and CD25 on cells activated for $24 \mathrm{~h}$ in the absence or presence of $1 \mu \mathrm{M} \mathrm{La}^{3+}$. Figure 5 shows that $\mathrm{La}^{3+}$ blocks the membrane expression of these two activation markers, indicating that $\mathrm{Ca}^{2+}$ influx is necessary to T-cell activation. SK\&F 96365, a known inhibitor of $\mathrm{Ca}^{2+}$ entry [21], had a similar, although lower, effect at $3 \mu \mathrm{M}$ (Figure 5). That concentration was enough to abrogate the CD3and thapsigargin-induced plateau of $\left[\mathrm{Ca}^{2+}\right]_{\mathrm{i}}$ increase by $90 \%$. Higher concentrations could not be used owing to the toxicity of this compound (results not shown). 


\section{DISCUSSION}

In the present study, the efficacy of $\mathrm{Ca}^{2+}$ entry compared with release from intracellular stores at activating Jurkat cells was studied. We first demonstrated that $\mathrm{La}^{3+}$ was able to inhibit $\mathrm{Ca}^{2+}$ influx in the absence of modifications of $\mathrm{Ca}^{2+}$ release from intracellular compartments. This was verified both in CD3- and thapsigargin-treated cells in which submicromolar $\mathrm{La}^{3+}$ concentrations totally blocked the $\mathrm{Ca}^{2+}$ influx without changes in $\mathrm{Ca}^{2+}$ release from the internal $\mathrm{Ca}^{2+}$ stores. The biosynthesis of PtdSer through the $\mathrm{Ca}^{2+}$-dependent base-exchange enzyme system located in the endoplasmic reticulum reflects the status (full/ empty) of the $\mathrm{Ca}^{2+}$ stores. We have thus used this original tool to follow the $\mathrm{Ca}^{2+}$ content of the $\mathrm{Ca}^{2+}$ stores. The inhibition of PtdSer synthesis induced by either CD3 or thapsigargin was not affected by $\mathrm{La}^{3+}$, indicating that this ion does not interfere with the process leading to $\mathrm{Ca}^{2+}$ release. Because CRAC also allows $\mathrm{Mn}^{2+}$ to penetrate the cells [18-20], we have measured the uptake of $\mathrm{Mn}^{2+}$ in CD3- and thapsigargin-treated cells. It was found that $\mathrm{Mn}^{2+}$ entry was also blocked by $\mathrm{La}^{3+}$. As $\mathrm{Mn}^{2+}$ enters the thapsigargin-stimulated cells it is very likely that this ion penetrates via CRAC, because thapsigargin does not open other channel types. Given the fact that $\mathrm{La}^{3+}$ does not penetrate Jurkat cells, as confirmed by the reversion of its effect by low EGTA concentrations, it was concluded that $\mathrm{La}^{3+}$ specifically blocks

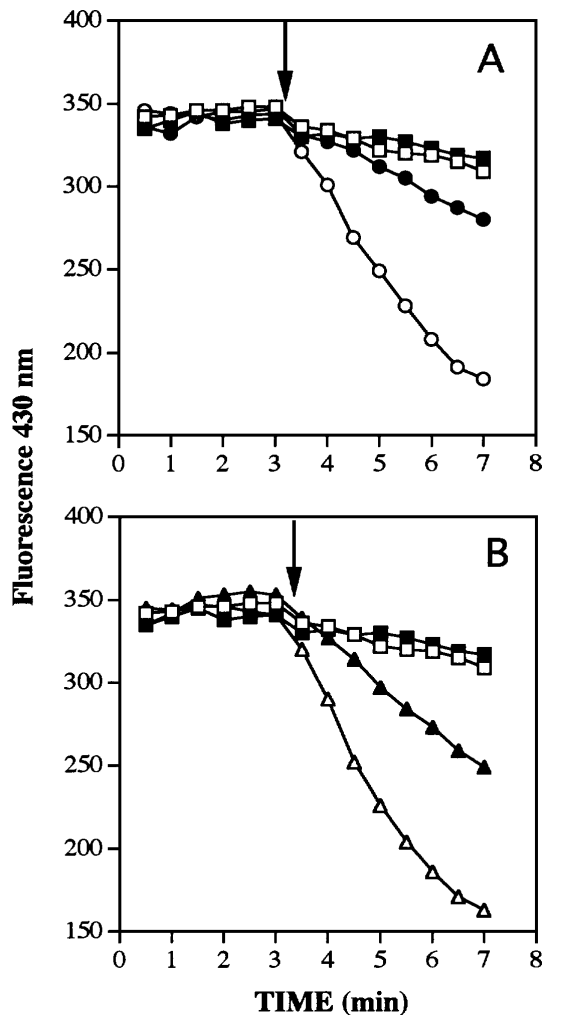

\section{Figure $4 \mathrm{La}^{3+}$ blocks $\mathrm{Mn}^{2+}$ entry into Jurkat cells}

The entry of $\mathrm{Mn}^{2+}$ into Jurkat cells was measured by the quenching of Indo- 1 fluorescence at $430 \mathrm{nM}$. Controls included untreated cells $(\square)$ and cells treated at time 0 with $1 \mu \mathrm{M} \mathrm{La}{ }^{3+}$ (ם). (A) Cells were additionally treated at time 0 with $\mathrm{CD} 3 \mathrm{mAb}$ alone $(\mathrm{O})$ or in the presence of $\mathrm{La}^{3+}(\mathbf{O})$. (B) Cells were treated with $10^{-7} \mathrm{M}$ thapsigargin alone $(\triangle)$ or in the presence of $1 \mu \mathrm{M} \mathrm{La}{ }^{3+}(\boldsymbol{\Delta})$. The fluorescence of Indo-1 at $430 \mathrm{~nm}$ was followed during a first period of $3 \mathrm{~min}$ to show the complete $\mathrm{Ca}^{2+}$ independence of Indo-1 fluorescence at $430 \mathrm{~nm}$; then $100 \mu \mathrm{M} \mathrm{Mn}^{2+}$ was added (indicated by an arrow) and the quenching of fluorescence was monitored for an additional $5 \mathrm{~min}$. During the whole experiment cells were in medium containing $1 \mathrm{mM} \mathrm{Ca}^{2+}$. These results are representative of three independent experiments.

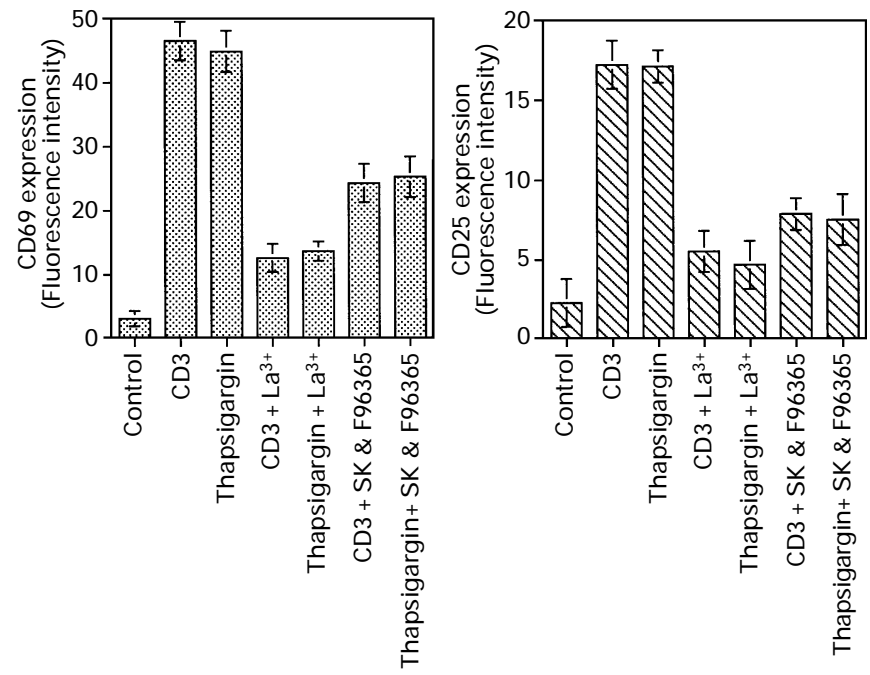

\section{Figure 5 Expression of CD69 and CD25 in activated Jurkat cells}

The expression of CD69 (left panel) and CD25 (right panel) was measured in controls and also in either CD3- or thapsigargin-treated cells. The effects of $\mathrm{La}^{3+}(1 \mu \mathrm{M})$ and SK\&F 96365 $(3 \mu \mathrm{M})$ were studied. Measurements were made by cytofluorimetry as indicated in the Materials and methods section. Results are expressed as means \pm S.D. for two experiments done in triplicate.

$\mathrm{Ca}^{2+}$ influx by plugging the CRAC. From these conclusions it was of interest to see whether some T-cell activation steps could be blocked by $\mathrm{La}^{3+}$. As shown in Figure 5, $\mathrm{La}^{3+}$ impaired CD25 and CD69 expression at the cell surface, indicating that the CRAC that maintains a high $\left[\mathrm{Ca}^{2+}\right]_{\mathrm{i}}$ is necessary for the expression of these two activation markers. This effect of $\mathrm{La}^{3+}$ is very probably due to $\mathrm{Ca}^{2+}$ entry blockade because: (1) it was observed in cells treated with thapsigargin, which bypasses the early signalling cascade triggered by TCR stimulation, and (2) a similar inhibition was obtained independently with the $\mathrm{Ca}^{2+}$ channel blocker SK\&F 96365. Conversely, it can be concluded that the first activation signals such as tyrosine kinase activation, phospholipase $\mathrm{C} \gamma 1$ phosphorylation, phosphatidylinositol bisphosphate hydrolysis and $\mathrm{IP}_{3}$-induced $\mathrm{Ca}^{2+}$ release from intracellular stores are not sufficient to induce CD25 and CD69 expression.

This work was supported by INSERM and the Association pour la Recherche Contre le Cancer (ARC).

\section{REFERENCES}

1 Weiss, A., Koretzky, G., Schatzman, R. C. and Kadlecek, T. (1991) Proc. Natl. Acad. Sci. U.S.A. 88, 5484-5488

2 Granja, C., Lin, L. L., Yunis, E. J., Relias, V. and Dasgupta, J. D. (1991) J. Biol. Chem. 266, 16277-16280

3 Mustelin, T., Coggeshall, K. M., Isakov, N. and Altman, A. (1990) Science 247, 1584-1587

4 Berridge, M. J. and Irvine, R. F. (1984) Nature (London) 312, 315-321

5 Berridge, M. J. (1993) Nature (London) 361, 315-325

6 Randriamampita, C. and Tsien, R. Y. (1993) Nature (London) 364, 809-814

7 Mason, M. J., Mahaut-Smith, M. P. and Grinstein, S. (1991) J. Biol. Chem. 266, 10872-10879

8 Mason, M. J., Garcia-Rodriguez, C. and Grinstein, S. (1991) J. Biol. Chem. 266, 20856-20862

9 Kwan, C. Y., Takemura, H., Obie, J. F., Thastrup, O. and Putney, J. W., Jr. (1990) Am. J. Physiol. 258, C1006-C1015

10 Foskett, J. K. and Wong, D. C. P. (1994) J. Biol. Chem. 269, 31525-31532

11 Chiono, M., Mahey, R., Tate, G. and Cooper, D. M. F. (1995) J. Biol. Chem. 270, 1149-1155 
12 Grynkiewicz, G., Poenie, M. and Tsien, R. Y. (1985) J. Biol. Chem. 260, 3440-3450

13 Bligh, E. G. and Dyer, W. (1959) Can. J. Biochem. Physiol. 37, 911-916

14 Pelassy, C., Breittmayer, J. P., Mary, D. and Aussel, C. (1991) J. Lipid Mediators 4. $199-210$

15 Pelassy, C., Breittmayer, J. P. and Aussel, C. (1992) Biochem. J. 288, 785-789

16 Breittmayer, J. P., Pelassy, C., Cousin, J. L., Bernard, A. and Aussel, C. (1993) J. Biol. Chem. 268, 20812-20817

Received 30 May 1995/25 September 1995; accepted 28 September 1995
17 Breittmayer, J. P., Bernard, A. and Aussel, C. (1994) J. Biol. Chem. 269, 5054-5058

18 Montero, M., Alvarez, J. and Garcia-Sancho, J. (1990) Biochem. J. 271, 535-540

19 Alvarez, J., Montero, M. and Garcia-Sancho, J. (1991) Biochem. J. 274, 193-197

20 Alonzo, M. T., Alvarez, J., Montero, M., Sanchez, A. and Garcia-Sancho, J. (1991) Biochem. J. 280, 783-789

21 Chiono, M., Mahey, R., Tate, G. and Cooper, D. M. F. (1995) J. Biol. Chem. 270 1149-1155 